\title{
Oncologic outcomes following surgical management of clinical stage II sex cord stromal
} tumors

Adam C. Calaway MD ${ }^{\mathrm{a}^{*}}$, Isamu Tachibana ${ }^{\mathrm{a}}$, Timothy A. Masterson MD ${ }^{\mathrm{a}}$, Richard S. Foster

$\mathrm{MD}^{\mathrm{a}}$, Lawrence H. Einhorn $\mathrm{MD}^{\mathrm{b}}$ and Clint Cary MD MPH

${ }^{\mathrm{a}}$ Indiana University School of Medicine, Department of Urology

${ }^{\mathrm{b}}$ Indiana University School of Medicine, Department of Oncology

*Corresponding Author:

Adam C Calaway

535 N Barnhill Dr. Suite 150

Indianapolis, IN 46202

Phone: 317-278-4881

Fax: 317-278-0499

e-mail:calawaya@iupui.edu

Affiliation: Indiana University School of Medicine, Department of Urology

Running Title: Outcomes after RPLND for CS II Sex Cord Stromal Tumors

Word Count of Abstract: 226

Word Count of Text: 2,399

Tables: 1

Figures: 1

Funding: None

Abstract:

Objective: To investigate the clinical history of patients with clinical stage II sex cord stromal tumors who underwent RPLND at our institution.

Methods: Our prospectively maintained testicular cancer database was queried to identify patients who presented with or developed clinical stage II sex cord stromal tumors and underwent RPLND at our institution between 1980 and 2018. Demographic, clinical and 
pathological characteristics were reviewed. Kaplan-Meier curves were graphed to assess recurrence-free and overall survival.

Results: Fourteen patients were included in the study with a median age of 44.2 years. Four patients presented with clinical stage II disease and 10 patients developed metastatic disease during follow-up of initial clinical stage I disease with a median time to metastasis of 2.7 years (range: $0.4-19.5$ years). Of the 10 patients with orchiectomy pathology data available, all patients had at least 1 risk factor on testis pathology (mean: 2.9 risk factors). Nine patients received treatment prior to referral to our institution. All patients recurred post-RPLND at Indiana University. Median recurrence-free survival was 9.8 months. Twelve patients died of disease with a median overall survival of 14.4 months.

Conclusions: Metastatic sex cord stromal tumors are rare and are more resistant to standard treatment modalities than metastatic germ cell tumors. Patients presenting with sex cord stromal tumors should consider prophylactic primary RPLND in the setting of one or more pathological predictor of malignancy.

Keywords: Testicular Cancer, Sex Cord Stromal Tumors, Metastatic Disease, Retroperitoneal Lymph Node Dissection, Recurrence, Pathology

Abbreviations: CS - Clinical Stage; RPLND - Retroperitoneal Lymph Node Dissection; NDI National Death Index; mTOR - mammalian target of rapamycin

\section{Introduction:}

Testicular cancer is the most common solid malignancy in men aged 15-44 with an estimated 9,310 new diagnoses in the United States in $2018^{1}$. The overwhelming majority of these new 
cases $(\sim 95 \%)$ are histologically classified as germ cell tumors. The remaining cases $(\sim 5 \%)$ predominantly are classified as sex cord stromal tumors (Sertoli or Leydig Cell) ${ }^{2,3}$. Most sex cord stromal tumors are benign and orchiectomy alone is curative suggesting that surveillance is the most appropriate management strategy for the majority of men presenting Clinical Stage (CS) I disease ${ }^{4}$. However, $10 \%$ of sex cord stromal tumors exhibit malignant behavior. Pathological risk factors as outlined by Lee et al. have been proposed to better select the $10 \%$ of patients who exhibit malignant behavior who may benefit from further therapy ${ }^{5}$. However, little is known regarding the best treatment approach for patients presenting with or developing metastatic disease during surveillance.

The discovery of the combination of cisplatin-based chemotherapeutic regimens and aggressive retroperitoneal surgery when warranted for the treatment of men with metastatic germ cell tumors is arguably one of the most significant advances in cancer care in the last half century ${ }^{6}$. Previous to this, men with metastatic germ cell tumors had dismal survival rates of $5-10 \%$ which drastically improved to the modern rates ranging from $75 \%$ to greater than $90 \%{ }^{7,8}$. However, the efficacy of chemotherapy and aggressive surgery for the rare man presenting with or developing metastatic sex cord stromal tumors is limited to case studies and small case series which all report uninspiring results ${ }^{4,9}$.

Thus, in this study, we sought to describe our experience managing patients with CS II sex cord stromal tumors and report oncological outcomes after retroperitoneal lymph node dissection (RPLND).

\section{Materials and Methods:}




\section{Patient Selection:}

The Indiana University prospectively maintained and institutional review board approved testicular cancer database was queried to identify patients who presented with or developed CS II sex cord stromal tumors and underwent RPLND at our institution between 1980 and 2018. Patients were excluded if a definitive pathological diagnosis of a sex cord stromal tumor was unable to be confirmed or if the RPLND was performed for CS I disease. The records of the included patients were reviewed. Referring physicians and liying patients were directly contacted and interviewed. Referring physicians and hospital systems of deceased patients were contacted for medical records regarding treatment course from the time of RPLND until their last follow-up or death. Pertinent information obtained included date and location of recurrence, treatment at initial recurrence, treatment and site of further recurrences, and date of last followup.

Orchiectomy Pathologic Risk Factors:

The pathology reports were reviewed if available and assessed for pathological risk factors of aggressive disease as previously defined by Kim et al ${ }^{5}$. These risk factors included: tumor size $>5 \mathrm{~cm}$, presence of necrosis, moderate or severe nuclear atypia, lymphovascular invasion, infiltrating margins and $>5$ mitotic features per 10 high powered fields.

\section{Primary and Secondary Outcomes:}


The primary outcome was to assess how aggressive retroperitoneal surgery impacted recurrence-free and overall survival. Vital status, cause of death and date of death were obtained using the National Death Index (NDI). The NDI is a centralized database of death record information established by the National Center for Health Statistics to aid epidemiologists and medical investigators with mortality ascertainment ${ }^{10}$. Recurrence-free survival was calculated from the date of the RPLND until the date of initial recurrence if known, If the date of recurrence was unknown and the patient died of disease, recurrence-free survival was calculated from the time of RPLND until the time of death. Overall survival was calculated from the time of RPLND until the time of death. Patients with unknown death dates or patients still alive were censored at the time of last follow-up or last patient contact, whichever occurred later. Secondary outcomes include the description of recurrence patterns and the association between pathological risk factors in orchiectomy specimens with the development of metastatic disease.

Statistical Analysis:

Descriptive statistics including means and standard deviations (or median and ranges) and counts and frequencies were used to summarize continuous and categorical variables for the entire cohort, respectively. Median recurrence-free and overall survival were calculated and survival curves were graphed using the Kaplan-Meier method. All statistical analysis was conducted using SAS 9.4 (SAS Institute, Cary, NC).

\section{Results:}


Patient Characteristic and Clinical Course Prior to RPLND:

Overall 14 patients were included in this study. Pertinent data for the entire cohort is summarized in Table 1. The median age at initial diagnoses was 44.2 years (range: 14-67). The laterality of the primary tumor was left and right in seven patients each. Histology of the orchiectomy was Sertoli Cell in 6, Leydig in 3 and Sex Cord Unclassified in 5. Ten (71.4\%) men developed CS II disease during surveillance whereas 4 (29.6\%) men presented with CS II at initial presentation. The median time to metastasis in men with initial CS I disease was 2.7 years (range 0.4-19.5 years). Nine men had treatment prior to RPLND at our institution with some men having multimodal therapy. RPLND at an outside institution occurred in 4 men, whereas 5 were treated with systemic chemotherapy and 4 received retroperitoneal external beam radiation.

Orchiectomy Pathologic Risk Factors:

The pathology reports of 10 patients were able to be reviewed for known risk factors of aggressive disease. All ten patients had at least one pathological risk factor with a mean number of 2.9 risk factors. The most common risk factor present were moderate atypia (10 patients), necrosis ( 7 patients) and $>5$ mitosis (6 patients). 
Prior to RPLND, the retroperitoneal mass size was $<2 \mathrm{~cm}, 2-5 \mathrm{~cm}, 5-10 \mathrm{~cm}$ and $>10 \mathrm{~cm}$ in 2, 3, 4 and 5 patients, respectively. Four patients underwent postchemotherapy RPLND, 2 underwent re-do RPLND and 8 underwent primary RPLND. Ten patients had bilateral template dissections, and 4 had modified unilateral dissections. No patients underwent a nerve-sparing procedure. Additional procedures at the time of RPLND were common including nephrectomies (4), bowel resections/repairs (4), aortic graphs (2), retrocrual dissection (2), vena cava resection (1), and pelvic dissection (1). The mean length of stay was 8.84 days $(+/-6.69)$. The mean number of positive and total lymph nodes removed was $3.3(+/-2.26)$ and $13.3(+/-10.1)$, respectively.

Recurrence patterns, Recurrence-Free Survival and Treatment at Recurrence:

All patients recurred postoperatively with a median recurrence-free survival of 9.8 months (Figure 1). The recurrence locations included in-field, out-of-field abdominal and extraabdominal (Table 1). Four patients received adjuvant chemotherapy immediately after the RPLND and two additional patients were known to receive multiple chemotherapy regimens for recurrence. Four patients underwent subsequent surgeries for recurrences including 1 patient who underwent multiple procedures including a hepatectomy (2), omentectomy, pelvic mass resection, paracolic and colon resection, re-do RPLND, and a splenectomy. The additional surgeries of the other three patients are listed in Table 1.

Overall Survival: 
Twelve $(85.7 \%)$ of the patients died of disease with a median overall survival of 14.4 months (Figure 1). The two patients who are currently alive are living with disease and on investigational treatments 24 and 46 months since the time of RPLND, respectively. One of the living patients recurred diffusely in the retroperitoneum. His tumor was sent for genomic analysis which indicated a susceptibility to Apalutamide, an androgen receptor antagonist, for which he has been taking for the last 4 months. The other living patient has undergone multiple surgeries and chemotherapeutic regimens since his RPLND. Notably, this patient's tumor was also sent for genomic analysis which indicated a susceptibility to Everolimus which is a mammalian target of rapamycin (mTOR) inhibitor. Treatment with this medication resulted in stable or slightly regressing metastatic disease for 12 months.

\section{Comment:}

Our current study describes the natural history of patients presenting with or developing metastatic sex cord stromal tumors. Over a nearly four-decade period, only 14 patients met this inclusion criteria highlighting the rarity of this aggressive phenotype. However, when metastatic disease occurs, recurrence-free and overall survival after aggressive retroperitoneal surgery was 9.8 and 14.4 months, respectively. Our results suggest that metastatic sex cord stromal tumors are resistant to multimodal cisplatin-based chemotherapy, aggressive surgical resection and radiotherapy which drastically contradicts the life-saving capabilities of these treatment modalities in men with germ cell tumors. As a result of these poor outcomes in the setting of metastatic disease, patients presenting with CS I sex cord stromal tumors should consider 
prophylactic primary RPLND in the setting of one or more pathological predictors of malignancy.

Recently, the National Cancer Database was utilized to evaluate patterns of care and survival outcomes for men diagnosed with sex cord stromal tumors. Over a 12-year period, only 315 cases $(0.39 \%$ of all testicular cancer cases $)$ were identified with the majority being Leydig Cell tumors. A few interesting trends were observed. First, regardless of tumor histology, men with CS I disease had lower 5-year Overall Survival then what would be expected for men with germ cell tumors (5-year OS for Leydig, 91\%; Sertoli 77\%). Second, the majority of men with CS I disease did not receive adjuvant treatment after orchiectomy. Third, even when analyzing a population-based database, investigation into treatment trends and response for men with CS II was impossible as only 30 men had at least CS II disease ${ }^{11}$. This analysis suggests that given the inferior survival outcomes, increasing the utilization of RPLND for CS I disease may be of potential benefit. A major limitation in the analysis, however, was the inability to investigate pathological risk factors of aggressive disease in orchiectomy specimens which has been proposed as a selection criteria for patients who should consider adjuvant therapy ${ }^{5,9}$.

The importance of pathological risk factors in orchiectomy specimens has been investigated in other case series. In a case series of 38 patients diagnosed with sex cord stromal tumors over a 25 -year period in England, high-risk orchiectomy features were rarely observed and patients universally were cured with orchiectomy alone ${ }^{12}$. Similarly, 37 of 48 patients diagnosed with sex cord stromal tumors and managed at Memorial Sloan Kettering over a 15year period had 0 or 1 pathological risk factors. All of these patients were managed with 
observation after orchiectomy and none of the patients recurred or progressed with relatively short follow-up (14.5 months $)^{9}$. These results suggest that orchiectomy alone is curative in men in the absence of pathological risk factors. Conversely, six men in the cohort from Memorial Sloan Kettering with $\geq 2$ high-risk orchiectomy features and CS I disease underwent prophylactic RPLND. Two of these men were found to have disease recurrence and progression after RPLND and ultimately died of their disease. Moreover, men with high-risk features on orchiectomy who were initially observed and underwent RPLND at the time of recurrence universally developed disease recurrence and progression ${ }^{9}$. The poor results of RPLND for men at the time of disease progression after initial observation were further confirmed in two other studies ${ }^{4,13}$.

Collectively, these studies support the findings of our current study. RPLND at the time of CS II disease is associated with poor outcomes and arguably should be done only in highly selected situations. Risk features on orchiectomy appeár to have a predictive ability to identify patients that may recur during periods of observation. The number of risk features in the orchiectomy (1 vs 2 or more) for which a primary RPLND should be offered is unknown. A systematic review of 47 studies and 292 patients further confirmed the prognostic importance of orchiectomy risk factors. Men with CS I disease and >2 risk factors had a 5-year DFS of $44.9 \%$ which was drastically lower than those with 1 or less risk factor. However, men with only 1 risk factor made up $11.1 \%$ of all recurrences therefore suggesting that a more conservative cut-off of 1 or more risk factor as a criteria for RPLND is reasonable ${ }^{14}$. Whether or not the lack of risk factors is universally predictive of benign behavior is speculative.

The current study must be viewed in the context of certain limitations. First, the strength of evidence of a single institution small case series is low. Given the rarity of the disease, the 
ability to perform randomized controlled trials investigating treatment regimens is unrealistic. Further work on this matter should focus on multi-institutional pooling of patients to further strengthen and improve the generalizability of the results. However, given the small number of CS II sex cord stromal tumors identified using population databases, the importance of single institutional case series for rare diseases or clinical situations remains ${ }^{11}$. Second, the pattern of recurrence and treatment at time of recurrence is unknown for a portion of the patients in our cohort. We attempted to mitigate this by directly contacting referring physicians and healthcare systems. Nevertheless, our primary conclusions remain valid due to the retrieval of vital status and cause of death (if applicable) information for the entire cohort.

These limitations notwithstanding, we believe that the results of our study sufficiently adds to the body of literature by describing the clinical history after RPLND for men with CS II sex cord stromal tumors. Men who present with or develop macroscopic metastatic sex cord stromal tumors comparatively do worse than men diagnosed with metastatic germ cell tumors. The oncological benefit of aggressive multimodal treatment in these men is debatable. Deciding to proceed with aggressive surgery in this cohort should only be done in select situations after multidisciplinary discussion. The fate of men with microscopic metastatic disease at initial presentation remains unknown and the role of surgical therapy in this cohort is speculative; however, due to the lack of effective therapies for metastatic disease, providers and patients should consider primary RPLND for CS I disease with 1 or more pathological risk factor for malignancy. Due to the high discrepancy of pathological interpretation between community hospitals and tertiary referral centers for germ cell tumors, we suggest that all sex cord stromal tumors are pathologically reviewed for the presence of adverse factors and primary RPLNDs 
performed, if advised, at centers with extensive experience managing advanced testicular cancer 15

\section{Conclusion:}

Metastatic sex cord stromal tumors are rare. In our experience, aggressive retroperitoneal surgery in men with macroscopic metastatic disease is not associated with the same oncological efficacy as surgery in men with germ cell tumors. Given the lack of effective therapies for men with macroscopic metastatic disease, we suggest considering prophylactic primary RPLND in men with 1 or more pathological risk factors for malignancy.

\section{References:}

1. Siegel RL, Miller KD, Jemal A. Cancer statistics, 2018. CA Cancer J Clin. 2018;68(1):730. doi:10.3322/caac. 21442 .

2. Dilworth JP, Farrow GM, Oesterling JE. Non-germ cell tumors of testis. Urology. 1991;37(5):399-417.

3. Acar C, Gurocak S, Sozen S. Current treatment of testicular sex cord-stromal tumors: critical review. Urology. 2009;73(6):1165-1171. doi:10.1016/j.urology.2008.10.036.

4. Mosharafa AA, Foster RS, Bihrle R, et al. Does retroperitoneal lymph node dissection have a curative role for patients with sex cord-stromal testicular tumors? Cancer. 2003;98(4):753-757. doi:10.1002/cncr.11573.

5. Kim I, Young RH, Scully RE. Leydig cell tumors of the testis. A clinicopathological analysis of 40 cases and review of the literature. Am J Surg Pathol. 1985;9(3):177-192.

6. Einhorn LH. Cis-Diamminedichloroplatinum, Vinblastine, and Bleomycin Combination Chemotherapy in Disseminated Testicular Cancer. Ann Intern Med. 1977;87(3):293-298. doi:10.7326/0003-4819-87-3-293. 
7. Einhorn LH. Treatment of testicular cancer: a new and improved model. J Clin Oncol. 1990;8(11):1777-1781. doi:10.1200/JCO.1990.8.11.1777.

8. Albany C, Adra N, Snavely AC, et al. Multidisciplinary Clinic Approach Improves Overall Survival Outcomes of Patients with Metastatic Germ Cell Tumors. Ann Oncol. November 2017. doi:10.1093/annonc/mdx731.

9. Silberstein JL, Bazzi WM, Vertosick E, et al. Clinical Outcomes of Local and Metastatic Testicular Sex Cord-Stromal Tumors. The Journal of Urology. 2014;192(2):415-419. doi:10.1016/j.juro.2014.01.104.

10. Centers of Disease Control and Prevention: National Center of Health Statistics. National Death Index. https://www.cdc.gov/nchs/ndi/index.htm. Published March 7, 2017.

Accessed October 28, 2018.

11. Banerji JS, Odem-Davis K, Wolff EM, Nichols CR, Porter CR. Patterns of Care and Survival Outcomes for Malignant Sex Cord Stromal Testicular Cancer: Results from the National Cancer Data Base. The Journal of Urology. 2016;196(4):1117-1122. doi:10.1016/j.juro.2016.03.143.

12. Featherstone JM, Fernando HS, Theaker JM, Simmonds PD, Hayes MC, Mead GM. Sex Cord Stromal Testicular Tumors: A Clinical Series - Uniformly Stage I Disease. The Journal of Urology. 2009;181(5):2090-2096. doi:10.1016/j.juro.2009.01.038.

13. Farkas LM, Székely JG, Pusztai C, Baki M. Hígh frequency of metastatic Leydig cell testicular tumours. Oncology. 2000;59(2):118-121. doi:10.1159/000012147.

14. Rove KO, Maroni PD, Cost CR, et al. Pathologic Risk Factors for Metastatic Disease in Postpubertal Patients With Clinical Stage I Testicular Stromal Tumors. Urology. 2016;97:138-144. doi:10.1016/j.urology.2016.06.066.

15. Harari SE, Sassoon DJ, Priemer DS, et al. Testicular cancer: The usage of central review for pathology diagnosis of orchiectomy specimens. Urol Oncol. 2017;35(10):605.e9605.e16. doi:10.1016/j.urolonc.2017.05.018.

\section{Legends:}



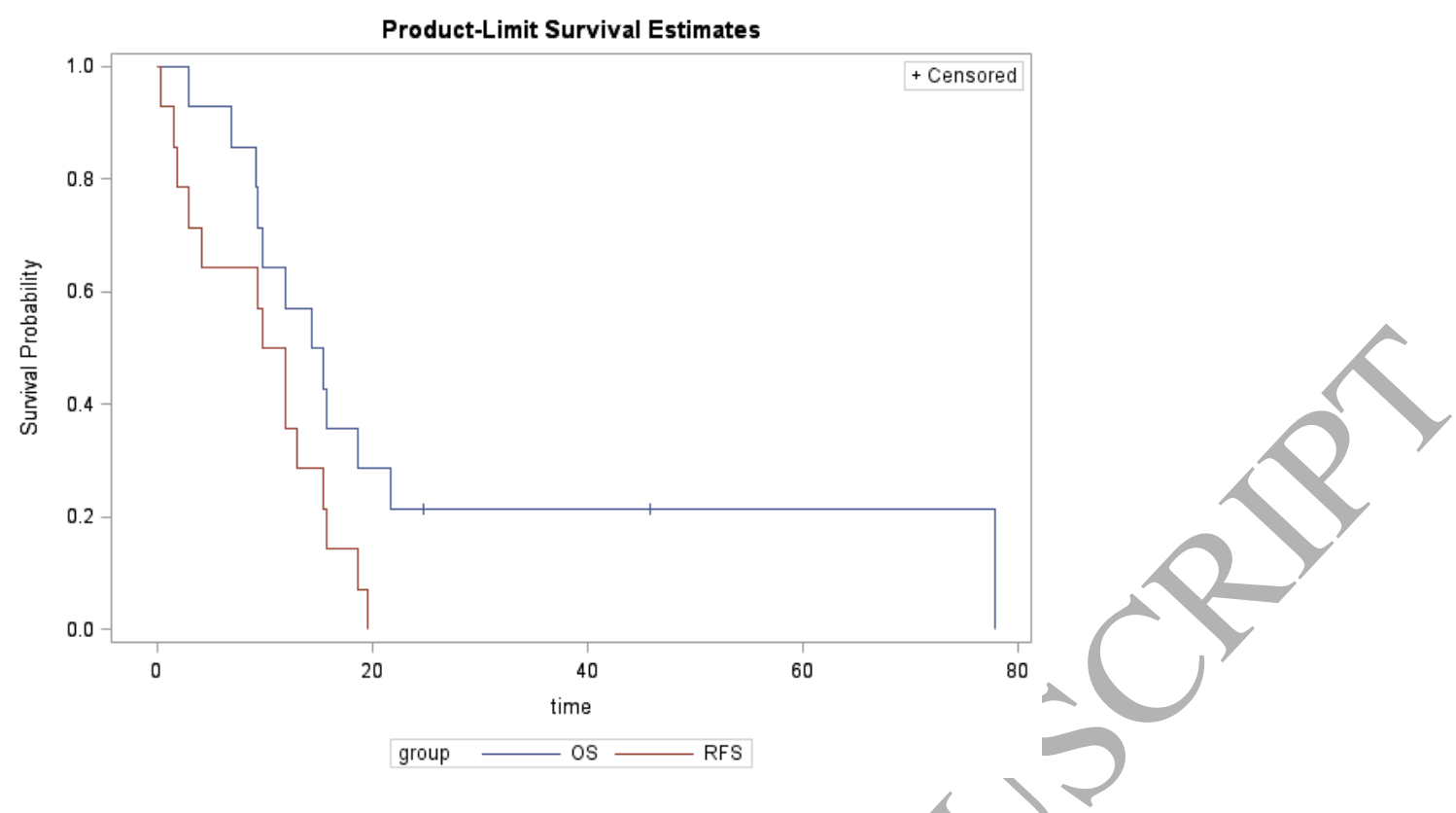

Figure 1: Recurrence-free (RFS) and Overall Survival (OS) in men with Clinical Stage II Sex Cord Stromal Tumors treated with Retroperitoneal Lymph Node Dissections 
Table 1: Patient-Specific Clinical Characteristics and Treatment Course of the Study Cohort

\begin{tabular}{|c|c|c|c|c|c|c|c|c|c|c|c|c|c|c|c|c|c|}
\hline $\begin{array}{l}\text { O } \\
b \\
\text { s }\end{array}$ & $\begin{array}{l}\text { Ye } \\
\text { ar } \\
\text { of } \\
\text { Di } \\
\text { ag } \\
\text { no } \\
\text { si } \\
\text { s }\end{array}$ & $\begin{array}{l}A \\
g \\
e \\
a \\
t \\
D \\
x\end{array}$ & $\begin{array}{l}\text { Hi } \\
\text { st } \\
\text { ol } \\
\text { og } \\
\text { y }\end{array}$ & $\begin{array}{l}\text { In } \\
\text { iti } \\
\text { al } \\
\text { C } \\
\text { li } \\
\text { ni } \\
\text { c } \\
\text { al } \\
\text { S } \\
\text { ta } \\
\text { g } \\
\text { e }\end{array}$ & $\begin{array}{l}\text { Tre } \\
\text { at } \\
\text { me } \\
\text { nt } \\
\text { Pri } \\
\text { or } \\
\text { to } \\
\text { RP } \\
\text { LN } \\
\text { D } \\
\text { at } \\
\text { IU }\end{array}$ & $\begin{array}{l}Y \\
e \\
a \\
r \\
0 \\
f \\
R \\
P \\
L \\
N \\
D\end{array}$ & $\begin{array}{l}T \\
y \\
p \\
e \\
0 \\
f \\
R \\
P \\
L \\
N \\
D\end{array}$ & $\begin{array}{l}\text { Te } \\
\mathrm{m} \\
\mathrm{pl} \\
\text { at } \\
\mathrm{e} \\
\text { of } \\
\mathrm{R} \\
\mathrm{P} \\
\mathrm{L} \\
\mathrm{N} \\
\mathrm{D}\end{array}$ & $\begin{array}{l}\text { Ad } \\
\text { diti } \\
\text { ona } \\
\text { I } \\
\text { Pro } \\
\text { ced } \\
\text { ure } \\
\text { s at } \\
\text { RP } \\
\text { LN } \\
\text { D }\end{array}$ & $\begin{array}{l}\text { RP } \\
\text { LN } \\
\text { D } \\
\text { Pat } \\
\text { hol } \\
\text { ogi } \\
\text { cal } \\
\text { Sta } \\
\text { ge }\end{array}$ & $\begin{array}{l}\text { Lo } \\
\text { ca } \\
\text { tio } \\
n \\
\text { of } \\
+\mathrm{L} \\
\mathrm{N} \\
\text { at } \\
\mathrm{R} \\
\mathrm{PL} \\
\mathrm{N} \\
\mathrm{D}\end{array}$ & $\begin{array}{l}\text { Adj } \\
\text { uva } \\
\text { nt } \\
\text { Ch } \\
\text { em } \\
\text { oth } \\
\text { era } \\
\text { py }\end{array}$ & $\begin{array}{l}\text { Add } \\
\text { itio } \\
\text { nal } \\
\text { Sur } \\
\text { ger } \\
\text { y } \\
\text { afte } \\
\text { r } \\
\text { RPL } \\
\text { ND }\end{array}$ & $\begin{array}{l}\text { Re } \\
\text { cu } \\
\text { rre } \\
\text { nc } \\
\text { e } \\
\text { Fr } \\
\text { ee } \\
\text { Su } \\
\text { rvi } \\
\text { val }\end{array}$ & $\begin{array}{l}\text { Loc } \\
\text { atio } \\
\text { n of } \\
\text { Rec } \\
\text { urre } \\
\text { nce( } \\
\text { s) }\end{array}$ & $\begin{array}{l}\text { Vi } \\
\text { ta } \\
\text { I } \\
S \\
\text { ta } \\
\text { tu } \\
s\end{array}$ & $\begin{array}{l}\text { O } \\
\text { v } \\
\text { er } \\
\text { al } \\
\text { I } \\
\text { S } \\
\text { ur } \\
\text { vi } \\
\text { v } \\
\text { al }\end{array}$ \\
\hline 1 & $\begin{array}{l}19 \\
81\end{array}$ & $\begin{array}{l}3 \\
5\end{array}$ & $\begin{array}{l}\text { Un } \\
\text { cla } \\
\text { ssi } \\
\text { fie } \\
\text { d } \\
\text { Se } \\
x \\
\text { Co } \\
\text { rd } \\
\text { Str } \\
\text { om } \\
\text { al } \\
\text { Tu } \\
\text { mo } \\
r\end{array}$ & $\begin{array}{l}\text { B } \\
3\end{array}$ & $\begin{array}{l}\text { Yes } \\
\text {; } \\
\text { Ch } \\
\text { em } \\
\text { oth } \\
\text { era } \\
\text { py }\end{array}$ & $\begin{array}{l}1 \\
9 \\
8 \\
1\end{array}$ & $\begin{array}{l}P \\
C \\
- \\
R \\
P \\
L \\
N \\
D\end{array}$ & $\begin{array}{l}\text { Fu } \\
\text { II } \\
\text { Bil } \\
\text { at } \\
\text { er } \\
\text { al }\end{array}$ & $\begin{array}{l}\text { Yes } \\
\text { Celi } \\
\text { ac } \\
\text { axis } \\
\text { and } \\
\text { less } \\
\text { er } \\
\text { sac } \\
\text { expl } \\
\text { orat } \\
\text { ion }\end{array}$ & B3 & $\begin{array}{l}\mathrm{Ce} \\
\text { lia } \\
\text { c } \\
\mathrm{Ax}\end{array}$ & Non & $\begin{array}{l}\text { Non } \\
\text { e }\end{array}$ & $\begin{array}{l}9.3 \\
6\end{array}$ & NA & $\begin{array}{l}\mathrm{D} \\
\mathrm{e} \\
\mathrm{a} \\
\mathrm{d} \\
\text { of } \\
\mathrm{Di} \\
\mathrm{s} \\
\mathrm{e} \\
\mathrm{a} \\
\mathrm{s} \\
\mathrm{e}\end{array}$ & $\begin{array}{l}9 . \\
3 \\
6^{+}\end{array}$ \\
\hline 2 & $\begin{array}{l}19 \\
81\end{array}$ & $\begin{array}{l}4 \\
2\end{array}$ & $\begin{array}{l}\text { Le } \\
\text { ydi }\end{array}$ & $A$ & & $\begin{array}{l}1 \\
9 \\
8 \\
6\end{array}$ & $\begin{array}{l}\mathrm{P} \\
\mathrm{ri} \\
\mathrm{m} \\
\mathrm{ar} \\
\mathrm{y}\end{array}$ & $\begin{array}{l}\text { Fu } \\
\text { II } \\
\text { Bil } \\
\text { at } \\
\text { er } \\
\text { al }\end{array}$ & $\begin{array}{l}\text { Yes } \\
\text { Nep } \\
\text { hre } \\
\text { cto } \\
\text { my, } \\
\text { pos } \\
\text { teri } \\
\text { or } \\
\text { me } \\
\text { dias } \\
\text { tinal } \\
\text { diss } \\
\text { ecti } \\
\text { on, }\end{array}$ & B3 & $\begin{array}{l}\mathrm{Pe} \\
\text { ria } \\
\text { ort } \\
\text { ic, } \\
\mathrm{Pe} \\
\text { Ivi } \\
\mathrm{C} \\
\text { an } \\
\mathrm{d} \\
\mathrm{M} \\
\text { edi } \\
\text { ast } \\
\text { ina } \\
\text { I }\end{array}$ & $\begin{array}{l}\text { Non } \\
\mathrm{e}\end{array}$ & $\begin{array}{l}\text { Non } \\
\mathrm{e}\end{array}$ & $\begin{array}{l}15 . \\
76\end{array}$ & NA & $\begin{array}{l}\mathrm{D} \\
\mathrm{e} \\
\mathrm{a} \\
\mathrm{d} \\
\text { of } \\
\mathrm{Di} \\
\mathrm{s} \\
\mathrm{e} \\
\mathrm{a} \\
\mathrm{s} \\
\mathrm{e}\end{array}$ & $\begin{array}{l}1 \\
5 . \\
7 \\
6\end{array}$ \\
\hline
\end{tabular}




\begin{tabular}{|c|c|c|c|c|c|c|c|c|c|c|c|c|c|c|c|c|c|}
\hline & & & & & & & & & $\begin{array}{l}\text { pelv } \\
\text { ic } \\
\text { lym } \\
\text { ph } \\
\text { nod } \\
\text { e } \\
\text { diss } \\
\text { ecti } \\
\text { on }\end{array}$ & & & & & & & & \\
\hline 3 & $\begin{array}{l}19 \\
92\end{array}$ & $\begin{array}{l}2 \\
7\end{array}$ & $\begin{array}{l}\mathrm{Se} \\
\text { rtol } \\
\mathrm{i}\end{array}$ & $\begin{array}{l}B \\
2 \\
C \\
1\end{array}$ & No & $\begin{array}{l}1 \\
9 \\
9 \\
2\end{array}$ & $\begin{array}{l}\mathrm{P} \\
\text { ri } \\
\mathrm{m} \\
\mathrm{ar} \\
\mathrm{y}\end{array}$ & $\begin{array}{l}\text { Fu } \\
\text { II } \\
\text { Bil } \\
\text { at } \\
\text { er } \\
\text { al }\end{array}$ & $\begin{array}{l}\text { Non } \\
\mathrm{e}\end{array}$ & $\begin{array}{l}\text { B2 } \\
\text { C1 }\end{array}$ & $\begin{array}{l}\mathrm{Pr} \\
\text { ec } \\
\text { av } \\
\text { al }\end{array}$ & $\begin{array}{l}\text { Yes } \\
; \\
1 . \\
\text { MAI } \\
D \\
2 . \\
\text { BE } \\
3 . \\
\text { Ora } \\
\text { VP- } \\
16 \\
4 . \\
\text { Unn } \\
\text { am } \\
\text { ed } \\
\text { four } \\
\text { th } \\
\text { regi } \\
\text { me } \\
\text { n }\end{array}$ & $\begin{array}{l}\text { Yes; } \\
1 . H \\
\text { epat } \\
\text { ecto } \\
\text { my } \\
\text { and } \\
\text { Om } \\
\text { ente } \\
\text { cto } \\
\text { my } \\
2 . \\
\text { Ex- } \\
\text { lap, } \\
\text { pelv } \\
\text { ic } \\
\text { mas } \\
\text { s } \\
\text { exci } \\
\text { sion } \\
\text { para } \\
\text { colic } \\
\text { mas } \\
\text { s } \\
\text { rese } \\
\text { ctio } \\
\text { n } \\
\text { with } \\
\text { en } \\
\text { bloc } \\
\text { cole } \\
\text { cto } \\
\text { my } \\
3 . \\
\text { Re- } \\
\text { Do } \\
\text { RPL }\end{array}$ & $\begin{array}{l}11 . \\
86 \\
y\end{array}$ & $\begin{array}{l}\text { Om } \\
\text { entu } \\
\text { m, } \\
\text { RU } \\
\text { Q } \\
\text { soft } \\
\text { tissu } \\
\text { e, } \\
\text { Live } \\
\text { r, } \\
\text { Pelv } \\
\text { ic } \\
\text { LN, } \\
\text { Perit } \\
\text { one } \\
\text { al } \\
\text { impl } \\
\text { ant, } \\
\text { colo } \\
\text { n, } \\
\text { Par } \\
\text { aspl } \\
\text { enic } \\
\text { LN, } \\
\text { Retr } \\
\text { oca } \\
\text { val } \\
\text { LN, } \\
\text { Pre } \\
\text { aorti } \\
\text { c LN }\end{array}$ & $\begin{array}{l}\text { D } \\
\text { e } \\
\text { a } \\
d \\
\text { of } \\
\text { Di } \\
\text { s } \\
\text { e } \\
\text { a } \\
\mathrm{s} \\
\text { e }\end{array}$ & $\begin{array}{l}7 \\
7 \\
8\end{array}$ \\
\hline
\end{tabular}




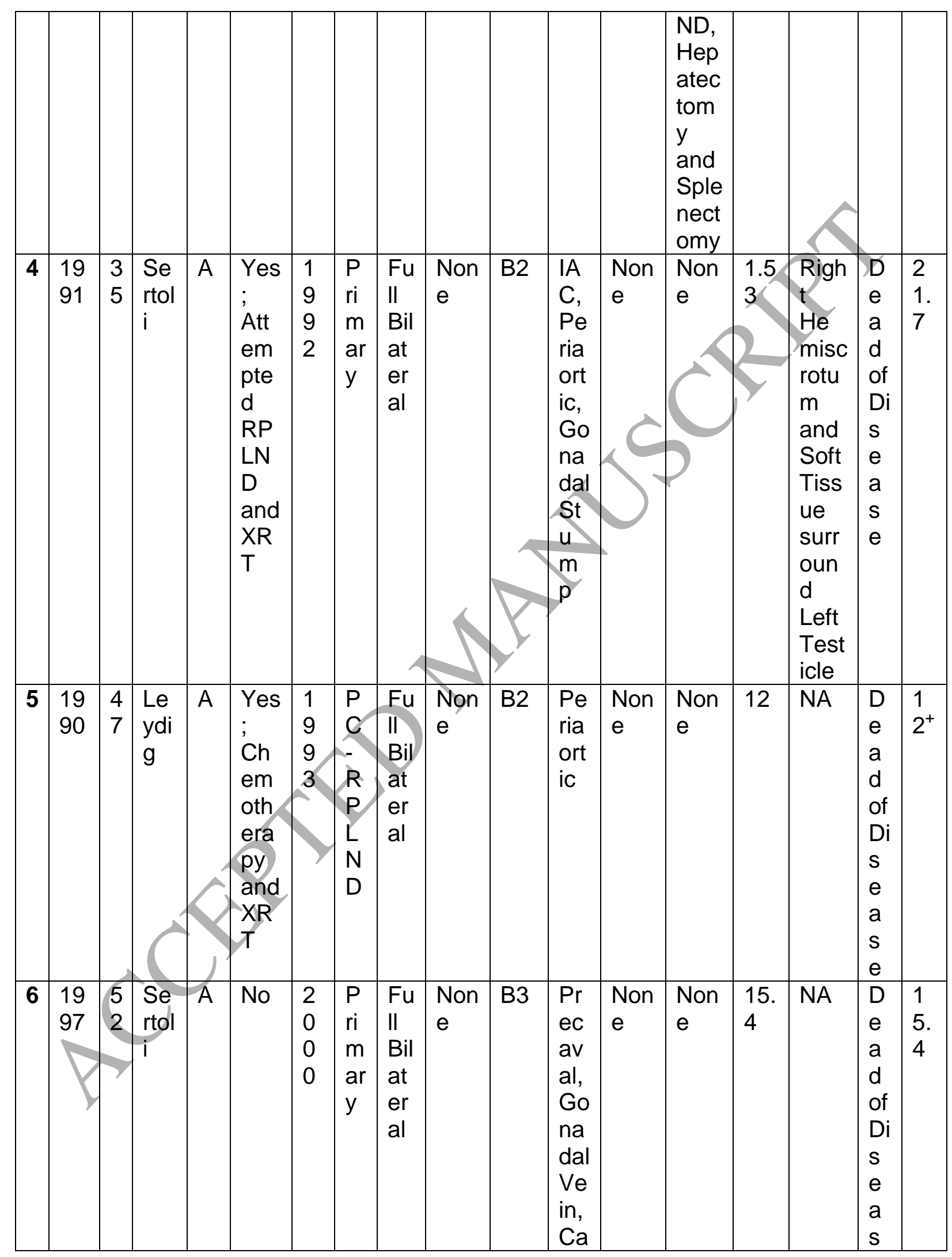




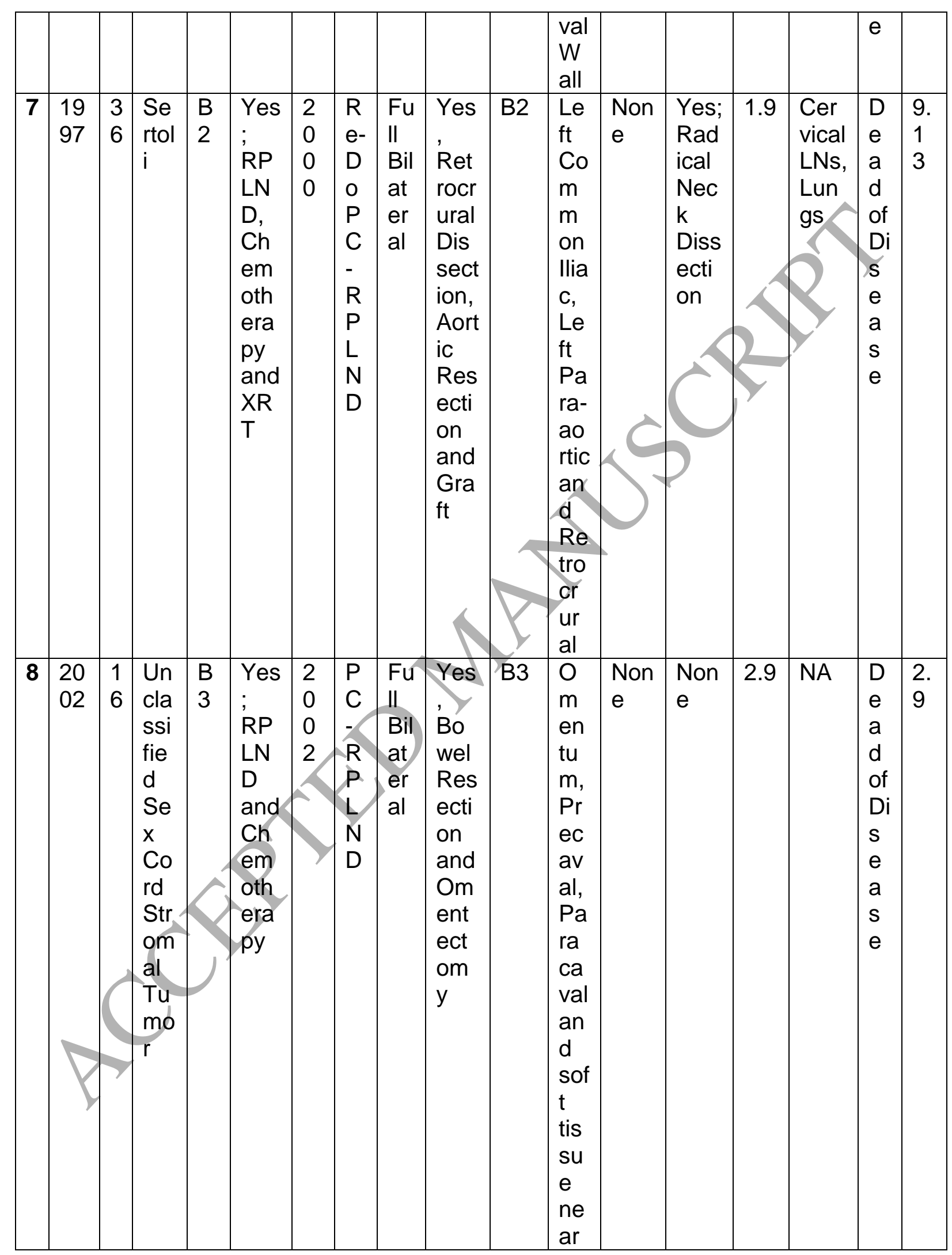




\begin{tabular}{|c|c|c|c|c|c|c|c|c|c|c|c|c|c|c|c|c|c|}
\hline & & & & & & & & & & & $\begin{array}{l}\text { iliu } \\
\text { m }\end{array}$ & & & & & & \\
\hline 9 & $\begin{array}{l}20 \\
01\end{array}$ & $\begin{array}{l}4 \\
6\end{array}$ & $\begin{array}{l}\text { Se } \\
\text { rtol } \\
\text { i }\end{array}$ & A & $\begin{array}{l}\text { Yes } \\
\text {; } \\
\text { XR } \\
\text { T }\end{array}$ & $\begin{array}{l}2 \\
0 \\
0 \\
3\end{array}$ & $\begin{array}{l}P \\
\text { ri } \\
m \\
a r \\
y\end{array}$ & $\begin{array}{l}\text { Fu } \\
\text { II } \\
\text { Bil } \\
\text { at } \\
\text { er } \\
\text { al }\end{array}$ & $\begin{array}{l}\text { Aort } \\
\text { ic } \\
\text { Res } \\
\text { ecti } \\
\text { on } \\
\text { and } \\
\text { Gra } \\
\text { ftin } \\
\mathrm{g}\end{array}$ & B2 & $\begin{array}{l}\mathrm{Pe} \\
\text { ria } \\
\text { ort } \\
\text { ic, } \\
\text { IA } \\
\text { C, } \\
\text { Ao } \\
\text { rta } \\
\text { Co } \\
\text { m } \\
\text { m } \\
\text { on } \\
\text { llia } \\
\text { c }\end{array}$ & $\begin{array}{l}\text { Non } \\
\mathrm{e}\end{array}$ & $\begin{array}{l}\text { Non } \\
\mathrm{e}\end{array}$ & $\begin{array}{l}14 . \\
43\end{array}$ & NA & $\begin{array}{l}\mathrm{D} \\
\mathrm{e} \\
\mathrm{a} \\
\mathrm{d} \\
\text { of } \\
\mathrm{Di} \\
\mathrm{s} \\
\mathrm{e} \\
\mathrm{a} \\
\mathrm{s} \\
\mathrm{e}\end{array}$ & $\begin{array}{l}1 \\
4 . \\
4 \\
3\end{array}$ \\
\hline $\begin{array}{l}1 \\
0\end{array}$ & $\begin{array}{l}19 \\
87\end{array}$ & $\begin{array}{l}4 \\
0\end{array}$ & $\begin{array}{l}\text { Un } \\
\text { cla } \\
\text { ssi } \\
\text { fie } \\
\text { d } \\
\text { Se } \\
\text { X } \\
\text { Co } \\
\text { rd } \\
\text { Str } \\
\text { om } \\
\text { al }\end{array}$ & $A$ & $\begin{array}{l}\text { Yes } \\
; \\
\text { RP } \\
\text { LN } \\
\text { D } \\
(20 \\
04)\end{array}$ & $\begin{array}{l}2 \\
0 \\
0 \\
6\end{array}$ & $\begin{array}{l}R \\
e- \\
D \\
O \\
R \\
P \\
L \\
\text { N } \\
D\end{array}$ & $\begin{array}{l}\text { M } \\
\text { od } \\
\text { ifi } \\
\text { ed } \\
\text { U } \\
\text { nil } \\
\text { at } \\
\text { er } \\
\text { al }\end{array}$ & $\begin{array}{l}\text { Yes } \\
\text { Nep } \\
\text { hre } \\
\text { cto } \\
\text { my, } \\
\text { Duo } \\
\text { den } \\
\text { ora } \\
\text { phy }\end{array}$ & B3 & $\begin{array}{l}\mathrm{Pe} \\
\text { ria } \\
\text { ort } \\
\text { ic }\end{array}$ & $\begin{array}{l}\text { Yes } \\
\text { Unk } \\
\text { now } \\
n\end{array}$ & $\begin{array}{l}\text { Non } \\
\mathrm{e}\end{array}$ & 9.8 & NA & $\begin{array}{l}\mathrm{D} \\
\mathrm{e} \\
\mathrm{a} \\
\mathrm{d} \\
\text { of } \\
\mathrm{Di} \\
\mathrm{s} \\
\mathrm{e} \\
\mathrm{a} \\
\mathrm{s} \\
\mathrm{e}\end{array}$ & $\begin{array}{l}9 . \\
8\end{array}$ \\
\hline $\begin{array}{l}1 \\
1\end{array}$ & $\begin{array}{l}20 \\
06\end{array}$ & $\begin{array}{l}5 \\
4\end{array}$ & $\begin{array}{l}\text { Le } \\
\text { ydi } \\
\text { g }\end{array}$ & $A$ & & 2 & $\begin{array}{l}\mathrm{P} \\
\mathrm{ri} \\
\mathrm{m} \\
\mathrm{ar} \\
\mathrm{y}\end{array}$ & $\begin{array}{l}\text { Fu } \\
\text { II } \\
\text { Bil } \\
\text { at } \\
\text { er } \\
\text { al }\end{array}$ & $\begin{array}{l}\text { Yes } \\
\text { 'Cav } \\
\text { al } \\
\text { Res } \\
\text { ecti } \\
\text { on }\end{array}$ & B2 & $\begin{array}{l}\text { IA } \\
\mathrm{C}, \\
\mathrm{Pa} \\
\text { ra } \\
\mathrm{ca} \\
\text { val }\end{array}$ & $\begin{array}{l}\text { Non } \\
\mathrm{e}\end{array}$ & $\begin{array}{l}\text { Non } \\
\mathrm{e}\end{array}$ & $\begin{array}{l}18 . \\
6\end{array}$ & $\begin{array}{l}\text { Live } \\
\mathrm{r}\end{array}$ & $\begin{array}{l}\mathrm{Li} \\
\mathrm{vi} \\
\mathrm{n} \\
\mathrm{g} \\
\mathrm{wi} \\
\mathrm{th} \\
\mathrm{Di} \\
\mathrm{s} \\
\mathrm{e} \\
\mathrm{a} \\
\mathrm{s} \\
\mathrm{e}\end{array}$ & $\begin{array}{l}1 \\
8 . \\
6^{+} \\
+\end{array}$ \\
\hline $\begin{array}{l}1 \\
2\end{array}$ & $\begin{array}{l}20 \\
02\end{array}$ & $\begin{array}{l}6 \\
2\end{array}$ & $\begin{array}{l}\text { Un } \\
\text { cla } \\
\text { ssi } \\
\text { fie } \\
\text { d }\end{array}$ & $A$ & No & $\begin{array}{l}2 \\
0 \\
1 \\
6\end{array}$ & $\begin{array}{l}P \\
\text { ri } \\
m \\
a r \\
y\end{array}$ & $\begin{array}{l}\text { M } \\
\text { od } \\
\text { ifi } \\
\text { ed } \\
\text { U }\end{array}$ & $\begin{array}{l}\text { Yes } \\
\text { Nep } \\
\text { hre } \\
\text { cto }\end{array}$ & B3 & $\begin{array}{l}\mathrm{Pe} \\
\text { ria } \\
\text { ort } \\
\text { ic }\end{array}$ & $\begin{array}{l}\text { Non } \\
\mathrm{e}\end{array}$ & $\begin{array}{l}\text { Non } \\
\mathrm{e}\end{array}$ & $\begin{array}{l}19 . \\
63\end{array}$ & $\begin{array}{l}\text { Retr } \\
\text { oper } \\
\text { iton } \\
\text { eal } \\
\text { near }\end{array}$ & $\begin{array}{l}\mathrm{Li} \\
\mathrm{vi} \\
\mathrm{n} \\
\mathrm{g} \\
\mathrm{wi}\end{array}$ & $\begin{array}{l}1 \\
9 . \\
8^{+} \\
+\end{array}$ \\
\hline
\end{tabular}




\begin{tabular}{|c|c|c|c|c|c|c|c|c|c|c|c|c|c|c|c|c|c|}
\hline & & & $\begin{array}{l}\text { Se } \\
\text { X } \\
\text { Co } \\
\text { rd } \\
\text { Str } \\
\text { om } \\
\text { al } \\
\text { Tu } \\
\text { mo } \\
\text { r }\end{array}$ & & & & & $\begin{array}{l}\text { nil } \\
\text { at } \\
\text { er } \\
\text { al }\end{array}$ & $\begin{array}{l}\text { my, } \\
\text { App } \\
\text { end } \\
\text { ect } \\
\text { om } \\
\text { y, } \\
\text { Part } \\
\text { ial } \\
\text { Duo } \\
\text { den } \\
\text { ect } \\
\text { om } \\
\text { y }\end{array}$ & & & & & & $\begin{array}{l}\text { pan } \\
\text { crea } \\
\text { s, } \\
\text { duo } \\
\text { den } \\
\text { um, } \\
\text { Par } \\
\text { aca } \\
\text { val } \\
\text { LN, } \\
\text { Left } \\
\text { Co } \\
\text { mm } \\
\text { on } \\
\text { iliac } \\
\text { LN, } \\
\text { IAC, } \\
\text { Sup } \\
\text { rahil } \\
\text { ar } \\
\text { LN }\end{array}$ & $\begin{array}{l}\text { th } \\
\mathrm{Di} \\
\mathrm{s} \\
\mathrm{e} \\
\mathrm{a} \\
\mathrm{s} \\
\mathrm{e}\end{array}$ & \\
\hline $\begin{array}{l}1 \\
3\end{array}$ & $\begin{array}{l}20 \\
13\end{array}$ & $\begin{array}{l}5 \\
2\end{array}$ & $\begin{array}{l}\text { Se } \\
\text { rtol } \\
\text { i }\end{array}$ & $A$ & $\begin{array}{l}\text { Yes } \\
\text {; } \\
\text { Ch } \\
\text { em } \\
\text { oth } \\
\text { era } \\
\text { py }\end{array}$ & $\begin{array}{l}2 \\
0 \\
1 \\
4\end{array}$ & $\begin{array}{l}P \\
C \\
- \\
R \\
P \\
L\end{array}$ & $\begin{array}{l}\text { M } \\
\text { od } \\
\text { ifi } \\
\text { ed } \\
\text { U } \\
\text { nil } \\
\text { at } \\
\text { er } \\
\text { al }\end{array}$ & $\begin{array}{l}\text { Non } \\
\text { e }\end{array}$ & & $\begin{array}{l}\mathrm{IA} \\
\mathrm{C}\end{array}$ & $\begin{array}{l}\text { Yes } \\
\text { EP }\end{array}$ & $\begin{array}{l}\text { Yes; } \\
1 . \\
\text { Part } \\
\text { ial } \\
\text { Pne } \\
\text { umo } \\
\text { nect } \\
\text { omy } \\
\text { x2 } \\
2 . \\
\text { Hep } \\
\text { atec } \\
\text { tom } \\
\text { y }\end{array}$ & 13 & $\begin{array}{l}\text { Che } \\
\text { st, } \\
\text { Med } \\
\text { iasti } \\
\text { num } \\
\text { ' } \\
\text { Retr } \\
\text { oper } \\
\text { iton } \\
\text { eum } \\
\text { Live } \\
\text { r, } \\
\text { Adr } \\
\text { enal }\end{array}$ & $\begin{array}{l}\mathrm{Li} \\
\mathrm{vi} \\
\mathrm{n} \\
\mathrm{g} \\
\mathrm{wi} \\
\text { th } \\
\mathrm{Di} \\
\mathrm{s} \\
\mathrm{e} \\
\mathrm{a} \\
\mathrm{s} \\
\mathrm{e}\end{array}$ & $\begin{array}{l}4 \\
0 . \\
3^{+} \\
+\end{array}$ \\
\hline $\begin{array}{l}1 \\
4\end{array}$ & $\begin{array}{l}20 \\
15\end{array}$ & $\begin{array}{l}6 \\
7\end{array}$ & $\begin{array}{l}\text { Un } \\
\text { cla } \\
\text { ssi } \\
\text { fie } \\
\text { d } \\
\text { Se } \\
\text { x } \\
\text { Co } \\
\text { rd } \\
\text { Str }\end{array}$ & A & No & $\begin{array}{l}2 \\
0 \\
1 \\
6\end{array}$ & $\begin{array}{l}\mathrm{P} \\
\mathrm{ri} \\
\mathrm{m} \\
\mathrm{ar} \\
\mathrm{y}\end{array}$ & $\begin{array}{l}\text { M } \\
\text { od } \\
\text { ifi } \\
\text { ed } \\
\text { U } \\
\text { nil } \\
\text { at } \\
\text { er } \\
\text { al }\end{array}$ & $\begin{array}{l}\text { Non } \\
\mathrm{e}\end{array}$ & B2 & $\begin{array}{l}\mathrm{Pe} \\
\text { ria } \\
\text { ort } \\
\text { ic } \\
\text { an } \\
\text { d } \\
\text { Go } \\
\text { na } \\
\text { dal } \\
\text { Ve }\end{array}$ & $\begin{array}{l}\text { Yes } \\
\text { EP }\end{array}$ & $\begin{array}{l}\text { Non } \\
\mathrm{e}\end{array}$ & 4.2 & $\begin{array}{l}\text { Par } \\
\text { atra } \\
\text { che } \\
\text { al } \\
\text { LN, } \\
\text { Med } \\
\text { iasti } \\
\text { niu } \\
\text { m, } \\
\text { Lun }\end{array}$ & $\begin{array}{l}\mathrm{D} \\
\mathrm{e} \\
\mathrm{a} \\
\mathrm{d} \\
\text { of } \\
\mathrm{Di} \\
\mathrm{s} \\
\mathrm{e} \\
\mathrm{a} \\
\mathrm{s}\end{array}$ & $\begin{array}{l}6 . \\
9\end{array}$ \\
\hline
\end{tabular}




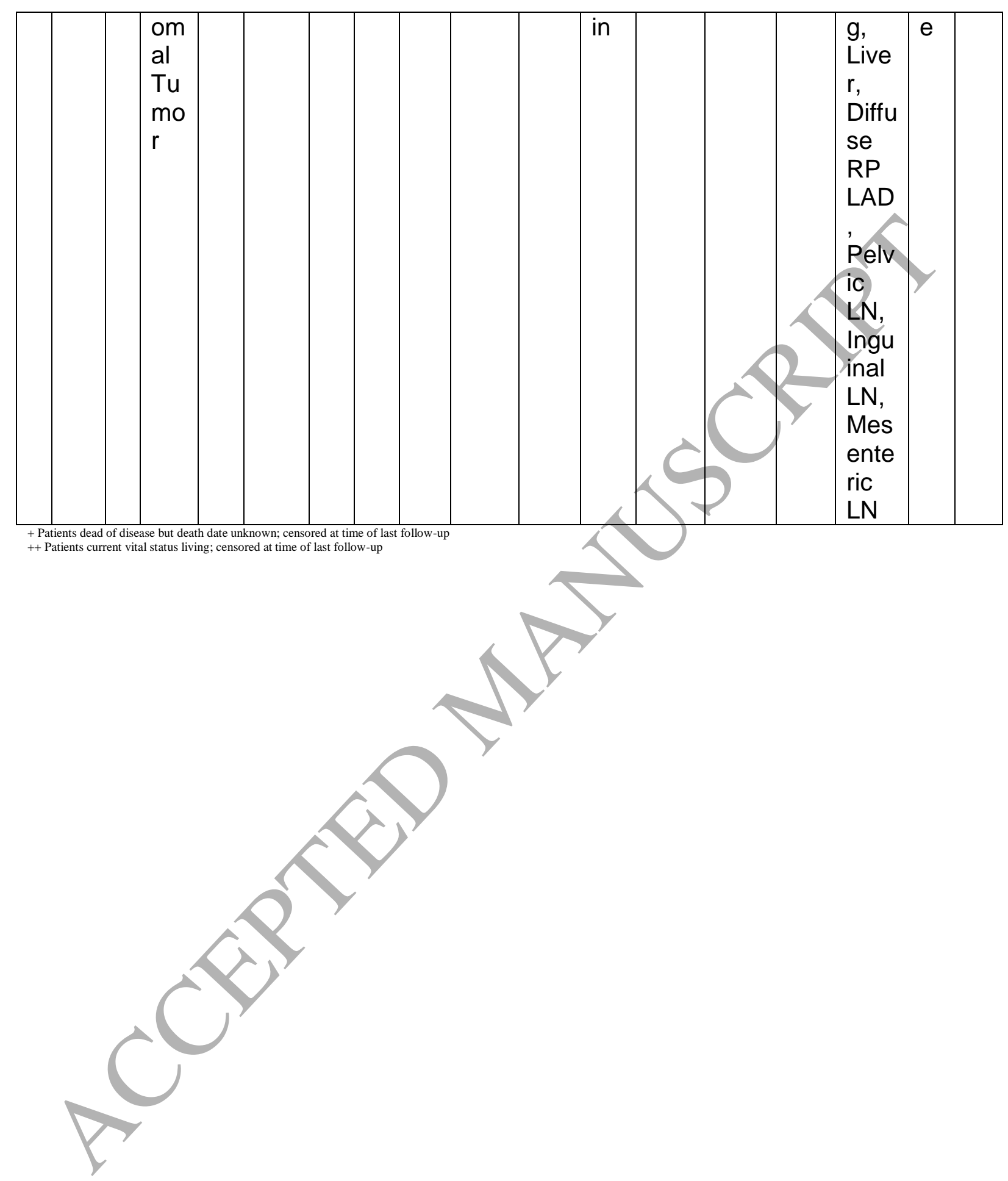

